\title{
Effects of Using Hazelnut Husk, Wood Shaving and of the Mixture at Different Thicknesses on Broiler Performances, Some Organ Weights, Foot-Pad Dermatitis and Litter Traits
}

\author{
Musa Sarıca, ${ }^{1, a}$, Kadir Erensoy ${ }^{1, b, *}$ \\ ${ }^{I}$ Department of Animal Science, Faculty of Agriculture, Ondokuz Mayis University, 55139 Samsun, Turkey
} ${ }^{*}$ Corresponding author

A R T I C L E IN F O A B S T R A C T

Research Article

Received : 26/04/2020

Accepted : 03/06/2020 \begin{abstract}
This study was carried out to determine the effects of the use of hazelnut husk (HH), wood shavings (WS) and the mixture of 50\% hazelnut husk $+50 \%$ wood shavings (MIX) in two different thicknesses (4 and $8 \mathrm{~cm}$ ) as a litter material in broiler production. The experiment was carried out as a factorial experimental design (3 litter type and 2 thickness) and stocking density was 10 chickens per $\mathrm{m}^{2}$. At $6 \mathrm{wk}$. of age, the effect of litter types and thicknesses on broiler live weights, feed efficiency, and livability, were not significant. Also, no differences were found in terms of gizzard, digestive tract, abdominal fat and edible internal organ weight percentages. While carcass yield varied between litter groups, there was no difference between litter thicknesses. The litter moisture levels at the end of the trial were not affected the litter type and litter thickness, while the foot pad dermatitis (FPD) rates were significantly affected. The highest FPD levels were determined in the HH litter and $4 \mathrm{~cm}$ thickness. As a result, the use of HH, WS and MIX of them with a thickness of 4 and $8 \mathrm{~cm}$ had no effect on other traits except for FPD levels. It has been observed that these litter materials may be used successfully in broiler production and use of $8 \mathrm{~cm}$ thickness litter has minor positive effects except that the cost of litter has doubled.
\end{abstract}

Hazelnut husk Wood shaving Litter thickness Broiler performance Foot pad dermatitis

\section{Introduction}

Deep floor system is widely used in broiler production all over the world. Litter is a material that prevents chickens from direct contact with house floor. A mixture of manure, urine, water and feather is produced during production. While the litter material provides a healthy environment for broilers with its isolation and water retention trait, on the other hand, it prevents the adverse effects caused by temperature and humidity changes in the house (Toledo et al., 2019). In many countries, wood shavings is the most preferred litter material in broiler production and the efficiency of using other litter materials is compared to wood shavings. It is usually supplied in 3-4 $\mathrm{cm}$ particle size from the wood-working and furniture industry. Increasing the use of wood shavings for other purposes in other areas of the industry has increased the cost in the poultry house and made it difficult to find (Ramadan et al., 2013; Garces et al., 2017).

In broiler production, the effects of reducing thickness by limiting the use of litter on performance, health and welfare standards are emphasized (Ekstrand et al., 1997; Monira et al., 2003; Sahao et al., 2015; Shepherd et al., 2017). On the other hand, studies investigating the use of some organic origin products obtained depending on local conditions (rice husk, hulls, sugar cane bagasse, wheat straw, soybean residue, corn cobs, stover, silage, composted municipial garbage, leaves and hazelnut husks, etc.) and their effectiveness according to wood shaving. Inorganic origin products (soils, clay minerals, zeolite and its derivatives, pumice stone, coal waste, sand, etc.) and the possibility of producing industrial type litter and using them in poultry houses are also investigated.

Turkey has $65-70 \%$ of the world hazelnut production and a significant amount of hazelnut husk emerges after the harvesting period. When this material is used as a litter, it is easier to vent the litter content due to the particle size (Sarıca et al., 1996). In addition, it may be used as a litter material for quail (Sarıca and Selcuk, 1993) and broiler production without any problems (Sarica and Cam, 2000). 
On the other hand, the fact that this product depends on the hazelnut harvest and the rains in the harvest period make it difficult for the product to be dried and stored, and the lack of sufficient data on the amount of litter to be used limits the use in broiler production.

Litter thickness affects to housing conditions, health and welfare parameters of chickens (Chou-Colli et al., 2018). Optimum values of litter thickness may vary by production systems, constitutional traits of house, climatic conditions and litter traits. Litter thickness does not significantly affect performance traits (Monira et al., 2003; Sogunle et al., 2006). However, some studies also state that broiler chickens cause differences in production and welfare parameters due to the litter thickness (Shao et al., 2015; Shepherd et al., 2017). While the increase in the litter thickness increases the cost, it may also affect the fertilizer value at the end of the production period. Generally, 5-7 $\mathrm{cm}$ litter thickness is considered sufficient in broiler production (Nowaczewski et al., 2011; Ramadan et al., 2013; Garces et al., 2013).

The effects of using hazelnut husk, wood shaving and their mixture as 4 and $8 \mathrm{~cm}$ litter thickness on growth, livability, feed intake, feed conversion ratio, foot-pad dermatitis (FPD), litter moisture level, some slaughtering traits and organ weights were revealed.

\section{Materials and Methods}

The study was conducted at the Ondokuz Mayis University Faculty of Agriculture's Research Farm. A total of 720-day old male-female mixed Ross-308 broiler chicks were used. Chicks were raised in a poultry house which can be heated naturally and artificially, ventilated by small windows and fans and white bulbs were used for lighting. The study was carried out in 30 pens of $165 \times 165 \mathrm{~cm}$ floor area and $180 \mathrm{~cm}$ height. The bottom sides of the pens were covered with wooden panel with $20 \mathrm{~cm}$ height and the litter transitions between the pens were prevented. A feeder with $15 \mathrm{~kg}$ capacity and an automatic round drinker are used and 24 chicks (10 chicks per $\mathrm{m}^{2}$ excluding equipment) were placed in each pen in accordance with the welfare conditions. At the beginning of the experiment, the chicks are numbered by wing-tagged and the body weights were determined by gender during the period.

Two days before the start of the study, wood shavings (WS), and hazelnut husk (HH) and of mixture (MIX) at 4 $\mathrm{cm}$ and $8 \mathrm{~cm}$ thickness were laid in each pen. In order to ensure that the initial moisture level is the same in all litter treatments, the house was heated for 2 days and the initial humidity values were determined. In order to provide a litter thickness standard, $9 \mathrm{~kg}$ of pens with $4 \mathrm{~cm}$ litter thickness and $18 \mathrm{~kg}$ litter were placed in the pens with 8 $\mathrm{cm}$ litter thickness. In the MIX group, an equal amount of mixture was provided from each litter type. In all the pens, $350 \mathrm{~g}\left(120 \mathrm{~g}\right.$ per $\left.\mathrm{m}^{2}\right)$ powdered lime was laid on the floor without placing litters.

The feeds used in the study were purchased from a commercial feed mill. Chickens were fed with broiler chick starter feed (\%23 protein and $3000 \mathrm{Kcal} / \mathrm{kg} \mathrm{ME})$ for the first 15 days, broiler chick feed (\%22 protein and 3100 $\mathrm{Kcal} / \mathrm{kg} \mathrm{ME}$ ) from 16 to 30 days, broiler chicken feed (\%20 protein and $3100 \mathrm{Kcal} / \mathrm{kg} \mathrm{ME}$ ) from 31 to 35 days and broiler finisher feed (\%20 protein and $3100 \mathrm{Kcal} / \mathrm{kg} \mathrm{ME}$ ) from 36 to slaughter age. Water and feed were provided adlibitum throughout the production period.

A 23-h light 1-h dark regime was applied during the first 21 d. From 22-42 d, lighting regime was applied 18-h light 6-h dark. Fluorescent white bulbs were used for lighting.

Chicks were vaccinated against Newcastle disease at 9 $\mathrm{d}$ of age, Gumboro disease at $21 \mathrm{~d}$ and Infectious Bronchitis at $29 \mathrm{~d}$ of age and no health problems were observed during the experiment.

In the experiment, individual body weights were taken firstly at placement in the house and 1, 2, 3, 4, 5 and 6 weeks of age. A $0.1 \mathrm{~g}$ precision scale was used in the first three weeks and a scale with $1 \mathrm{~g}$ precision was used in the following periods. The feed efficiencies (FCR) were calculated from weekly feed intake and body weights.

Mortalities are expressed as a percentage of deaths during the study. Foot pad dermatitis (FPD) scoring was performed on the left foot pad area of all chickens at $42 \mathrm{~d}$ of age. FPD scores were measured according to Mayne (2005); as follows: 0: no external signs of FPD; 1: raise central pad reticulate scales are separated, with or without small, black necrotic areas; 2: marked swelling of the foot pad, black reticulate scales forming scale-shaped necrotic areas, with necrosis evident on less than one-quarter of the total foot pad area; 3: marked swelling and enlargement of the entire foot pad, necrosis extending up to one-half of the total foot pad area 4: marked swelling and enlargement of the entire foot pad, necrotic cells covering more than onehalf of the total foot pad area. Litter moisture content was determined following slaughtering of chickens at $42 \mathrm{~d}$. Litter samples were collected from 3 different places in each pen and mixed together; $100 \mathrm{~g}$ of this mixture was dried at $60^{\circ} \mathrm{C}$ for $48 \mathrm{~h}$ after which moisture content were measured (Yamak et al., 2016).

Factorial analyses was conducted using a completely randomized design $(3 \times 2 \times 5)$, with litter type and litter thickness as factor on the data of performance, slaughtering traits, organ weights and litter moisture contents. Data recorded as percentages were subjected to arc-sine square root transformation, and real mean values were calculated and are presented in the tables. Gender was used as acovariate in the model and gender differentiation was not given in the tables. Differences among litter types means were identified using Duncan's multiple comparison test. Mortality rate of litter groups were assessed by the chisquare test. Kruskal-Wallis test was used to determine correlation between FPD scores. Kruskal-Wallis results showed the effect of litter type and thickness, therefore the Mann-Whitney-U test was used for 2-way comparisons between litter type and thickness, with results given as means, medians and standard error of means. A difference of $\mathrm{P}<0.05$ was considered statistically significant. All statistical analyses were conducted using SPSS (Version 21) for Windows software (SPSS Inc., Chiago, IL; Licenced by Ondokuz Mayis University).

\section{Results}

The effect of litter type and thickness on body weight and mortality rates of chickens are given in Table 1. Litter type did not affect the body weight except for the $4 \mathrm{wk}$. of age. Body weights of WS, HH and MIX groups were determined as $1530.3,1498.2$ and $1483.7 \mathrm{~g}$, respectively at 
4th wk. of age $(\mathrm{P}<0.05)$. Although body weight changes continued in this trend until the slaughtering age in the litter type groups, the differences were not significant. Higher body weights were determined in $8 \mathrm{~cm}$ litter thickness group at 1 and 2 wk. of age $(\mathrm{P}<0.05)$. The differences in mortality rates did not change by the litter type and thickness groups throughout the study.

The effect of litter type on feed intake at the $1 \mathrm{wk}$. of age was found significant $(\mathrm{P}<0.05)$, however litter type and thickness treatments had no significant effect on feed intake and feed conversion ratio in the following weeks (Table 2).

The percentages of edible inner organs (gizzard, liver and heart), abdominal fat and digestive tract did not differ according to litter type and thickness (Table 3). On the other hand, differences were found between litter types in terms of carcass yield values $(\mathrm{P}<0.05)$. The highest carcass yield was determined in chickens reared on WS and the lowest on $\mathrm{HH}$.
Wetting, caking or other negative conditions were not observed throughout the study (Table 4). Although the initial litter moisture level varies between 9.08 and $9.76 \%$; it has increased as time progressed. At the 3rd wk. of the study, only the differences in the moisture level of the litter types were found significant $(\mathrm{P}<0.05)$; the lowest moisture content determined in the WS and the highest in the $\mathrm{HH}$. This situation varied between 28-42 days when ventilation was performed at a higher level, and moisture levels were found similar in all groups. The differences were not significant during the study in terms of moisture levels related to the litter thickness.

The effects of litter type and thickness on FPD levels were found significant $(\mathrm{P}<0.05)$. Additionally, the highest FPD level was determined in chickens reared on the $\mathrm{HH}$ litter, and the FPD levels decreased due to the increase in the litter thickness $(\mathrm{p}<0.05$; Table 5).

Table 1 . Effect of litter type and thickness on body weight and mortality rates

\begin{tabular}{|c|c|c|c|c|c|c|c|c|c|}
\hline \multirow{2}{*}{$\mathrm{LT}$} & \multirow{2}{*}{$\mathrm{T}$} & \multicolumn{7}{|c|}{ Body weights (g, wk.) } & \multirow{2}{*}{$\begin{array}{c}\text { Mortality } \\
(\%, 0-6 \text { wk. })\end{array}$} \\
\hline & & Hatch & 1 & 2 & 3 & 4 & 5 & 6 & \\
\hline \multirow{2}{*}{ WS } & 4 & 41.6 & 164.3 & 450.6 & 871.8 & 1493.7 & 2165.2 & 2889.1 & 0.41 \\
\hline & 8 & 41.9 & 174.7 & 472.3 & 918.8 & 1566.9 & 2226.5 & 2958.0 & 0.00 \\
\hline \multirow{2}{*}{$\mathrm{HH}$} & 4 & 41.4 & 161.9 & 443.8 & 873.8 & 1496.6 & 2178.6 & 2895.1 & 0.80 \\
\hline & 8 & 42.0 & 169.5 & 453.9 & 884.4 & 1499.9 & 2183.8 & 2846.2 & 1.25 \\
\hline \multirow{2}{*}{ MIX } & 4 & 41.9 & 164.7 & 451.0 & 883.2 & 1488.6 & 2139.1 & 2836.3 & 0.00 \\
\hline & 8 & 42.7 & 165.7 & 449.1 & 874.4 & 1478.8 & 2150.0 & 2825.6 & 0.00 \\
\hline SEM & & 0,149 & 0.841 & 2.411 & 4.513 & 8.007 & 11.643 & 16.843 & 0.001 \\
\hline \multicolumn{10}{|c|}{ Main effects } \\
\hline LT & & NS & NS & NS & NS & $*$ & NS & NS & NS \\
\hline WS & & 41,8 & 169.5 & 461.5 & 895.3 & $1530.3^{\mathrm{a}}$ & 2195.8 & 2923.6 & 0.21 \\
\hline $\mathrm{HH}$ & & 41,7 & 165.7 & 448.9 & 879.1 & $1498.2^{\mathrm{ab}}$ & 2181.2 & 2870.7 & 1.03 \\
\hline MIX & & 41,8 & 165.2 & 450.1 & 878.8 & $1483.7^{b}$ & 2144.6 & 2830.9 & 0.00 \\
\hline $\mathrm{T}$ & & NS & $* *$ & $*$ & NS & NS & NS & NS & NS \\
\hline $4 \mathrm{~cm}$ & & 41,7 & 163.6 & 448.5 & 876.3 & 1493.0 & 2160.9 & 2873.5 & 0.40 \\
\hline $8 \mathrm{~cm}$ & & 41,9 & 170.0 & 458.5 & 892.5 & 1515.2 & 2186.7 & 2876.6 & 0.42 \\
\hline $\mathrm{L} \times \mathrm{T}$ & & NS & NS & NS & $*$ & NS & NS & NS & NS \\
\hline
\end{tabular}

LT: Litter type, WS: Wood shaving (WS), HH: Hazelnut husk (HH), T: Thickness (cm), ${ }^{\text {a, }}{ }^{\text {b: }}$ Means within same rows different superscripts are significantly different $(\mathrm{P}<0.05), *: \mathrm{P}<0.05 ; * *: \mathrm{P}<0.01 ; \mathrm{NS}: \mathrm{P}>0.05$.

Table 2. Effect of litter type and thickness on feed intake $(\mathrm{kg})$ and feed conversion ratio ( $\mathrm{kg} \mathrm{feed} / \mathrm{kg}$ body weight)

\begin{tabular}{|c|c|c|c|c|c|c|c|c|c|c|c|c|c|}
\hline \multirow{3}{*}{ LT } & \multirow{3}{*}{$\mathrm{T}$} & \multicolumn{12}{|c|}{ Feed intake (kg, wk) and feed conversion ratio ( $\mathrm{kg}$ feed/kg body weight, wk.) } \\
\hline & & \multicolumn{2}{|c|}{1} & \multicolumn{2}{|c|}{2} & \multicolumn{2}{|c|}{3} & \multicolumn{2}{|c|}{4} & \multicolumn{2}{|c|}{5} & \multicolumn{2}{|c|}{6} \\
\hline & & FI & FCR & FI & FCR & FI & FCR & FI & FCR & FI & FCR & FI & FCR \\
\hline \multirow{2}{*}{ WS } & 4 & 0.265 & 1.61 & 0.678 & 1.51 & 1.410 & 1.60 & 2.361 & 1.58 & 3.539 & 1.66 & 4.910 & 1,68 \\
\hline & 8 & 0.244 & 1.40 & 0.722 & 1.53 & 1.501 & 1.64 & 2.484 & 1.59 & 3.664 & 1.65 & 5.006 & 1,71 \\
\hline \multirow{2}{*}{$\mathrm{HH}$} & 4 & 0.244 & 1.51 & 0.684 & 1.54 & 1.451 & 1.66 & 2.407 & 1.60 & 3.573 & 1.64 & 4.931 & 1,70 \\
\hline & 8 & 0.244 & 1.50 & 0.661 & 1.51 & 1.405 & 1.59 & 2.337 & 1.56 & 3.503 & 1.61 & 4.826 & 1,67 \\
\hline \multirow{2}{*}{ MIX } & 4 & 0.241 & 1.50 & 0.696 & 1.54 & 1.428 & 1.62 & 2.383 & 1.60 & 3.528 & 1.65 & 4.812 & 1,70 \\
\hline & 8 & 0.240 & 1.47 & 0.693 & 1.56 & 1.386 & 1.59 & 2.305 & 1.56 & 3.465 & 1.61 & 4.785 & 1,69 \\
\hline SEM & & 1,691 & 0.151 & 7.092 & 0.561 & 17.132 & 0.703 & 20.203 & 0.903 & 22.144 & 0.282 & 35.193 & 0.733 \\
\hline \multicolumn{14}{|c|}{ Main effects } \\
\hline LT & & $*$ & NS & NS & NS & NS & NS & NS & NS & NS & NS & NS & NS \\
\hline WS & & $0,255^{\mathrm{a}}$ & 1.50 & 0.701 & 1.52 & 1.456 & 1.62 & 2.423 & 1.59 & 3.601 & 1.65 & 4.987 & 1.70 \\
\hline $\mathrm{HH}$ & & $0,244^{\mathrm{ab}}$ & 1.50 & 0.672 & 1.53 & 1.428 & 1.63 & 2.372 & 1.58 & 3.538 & 1.62 & 4.878 & 1.69 \\
\hline MIX & & $0,241^{\mathrm{b}}$ & 1.45 & 0.694 & 1.55 & 1.407 & 1.61 & 2.344 & 1.58 & 3.496 & 1.63 & 4.799 & 1.69 \\
\hline $\mathrm{T}$ & & NS & NS & NS & NS & NS & NS & NS & NS & NS & NS & NS & NS \\
\hline $4 \mathrm{~cm}$ & & 0,250 & 1.54 & 0.686 & 1.53 & 1.430 & 1.63 & 2.384 & 1.59 & 3.546 & 1.65 & 4.884 & 1.69 \\
\hline $8 \mathrm{~cm}$ & & 0,243 & 1.46 & 0.692 & 1.53 & 1.431 & 1.61 & 2.376 & 1.57 & 3.544 & 1.62 & 4.872 & 1.69 \\
\hline $\mathrm{L} \times \mathrm{T}$ & & NS & NS & $\mathrm{NS}$ & NS & NS & NS & NS & NS & NS & NS & NS & $\mathrm{NS}$ \\
\hline
\end{tabular}

LT: Litter type, WS: Wood shaving (WS), HH: Hazelnut husk (HH), T: Thickness (cm), a, b: Means within same rows different superscripts are significantly different $(\mathrm{P}<0.05)$, *: P<0.05; NS: P>0.05; FI: Feed intake (kg); FCR: Feed conversion ratio (kg feed/kg body weight). 
Table 3. Effect of litter type and thickness on percentages of edible inner organs, abdominal fat, digestive tract and carcass yield ${ }^{1}$

\begin{tabular}{|c|c|c|c|c|c|c|c|c|}
\hline \multirow{2}{*}{$\mathrm{LT}$} & \multirow{2}{*}{$\mathrm{T}$} & \multicolumn{7}{|c|}{$\%$ by body weight } \\
\hline & & Gizzard & Liver & Heart & Total & Abdominal fat & Digestive tract & Carcass yield \\
\hline \multirow{2}{*}{ WS } & 4 & 1.30 & 2.41 & 0.67 & 4.38 & 3.41 & 6.93 & 74.6 \\
\hline & 8 & 1.30 & 2.42 & 0.63 & 4.36 & 3.91 & 7.69 & 73.5 \\
\hline \multirow{2}{*}{$\mathrm{HH}$} & 4 & 1.32 & 2.42 & 0.67 & 4.42 & 3.40 & 8.41 & 72.9 \\
\hline & 8 & 1.48 & 2.39 & 0.68 & 4.55 & 3.38 & 8.64 & 72.8 \\
\hline \multirow{2}{*}{ MIX } & 4 & 1.35 & 2.56 & 0.72 & 4.63 & 3.53 & 8.29 & 73.2 \\
\hline & 8 & 1.45 & 2.31 & 0.65 & 4.41 & 3.35 & 8.47 & 73.8 \\
\hline SEM & & 0.031 & 0.042 & 0.017 & 0.052 & 0.124 & 0.144 & 0.192 \\
\hline \multicolumn{9}{|c|}{ Main effects } \\
\hline LT & & NS & NS & NS & NS & NS & NS & $*$ \\
\hline WS & & 1.30 & 2.42 & 0.65 & 4.37 & 3.67 & 7.33 & $74.0^{\mathrm{a}}$ \\
\hline $\mathrm{HH}$ & & 1.40 & 2.41 & 0.68 & 4.48 & 3.39 & 8.53 & $72.9^{\mathrm{b}}$ \\
\hline MIX & & 1.40 & 2.44 & 0.68 & 4.51 & 3.44 & 8.35 & $73.5^{\mathrm{ab}}$ \\
\hline $\mathrm{T}$ & & NS & NS & NS & NS & NS & NS & NS \\
\hline $4 \mathrm{~cm}$ & & 1.32 & 2.46 & 0.69 & 4.48 & 3.44 & 7.87 & 73.6 \\
\hline $8 \mathrm{~cm}$ & & 1.41 & 2.37 & 0.65 & 4.44 & 3.55 & 8.26 & 73.4 \\
\hline $\mathrm{L} \times \mathrm{T}$ & & NS & $\mathrm{NS}$ & NS & NS & NS & NS & NS \\
\hline
\end{tabular}

LT: Litter type, WS: Wood shaving (WS), HH: Hazelnut husk (HH), T: Thickness (cm), ${ }^{\text {a, }}{ }^{\text {b }}$ Means within same rows different superscripts are significantly different $(\mathrm{P}<0.05) . *: \mathrm{P}<0.05 ; \mathrm{NS}: \mathrm{P}>0.05,{ }^{1}:(\mathrm{g}$ weight/body weight $\left.) \times 100\right)$

Table 4. Effect of litter type and thickness on the litter moisture

\begin{tabular}{|c|c|c|c|c|c|c|c|c|}
\hline \multirow{2}{*}{ LT } & \multirow{2}{*}{$\mathrm{T}$} & \multicolumn{7}{|c|}{ Litter moisture (\%, wk) } \\
\hline & & Initial & 1 & 2 & 3 & 4 & 5 & 6 \\
\hline \multirow{2}{*}{ WS } & 4 & 9.76 & 10.08 & 11.40 & 14.20 & 19.54 & 24.23 & 26.26 \\
\hline & 8 & 9.00 & 9.90 & 10.32 & 14.22 & 17.63 & 23.03 & 26.16 \\
\hline \multirow{2}{*}{$\mathrm{HH}$} & 4 & 9.31 & 9.76 & 11.57 & 16.94 & 21.64 & 24.78 & 26.53 \\
\hline & 8 & 9.49 & 10.38 & 12.27 & 17.20 & 19.45 & 22.21 & 24.55 \\
\hline \multirow{2}{*}{ MIX } & 4 & 9.36 & 9.89 & 12.18 & 17.86 & 21.01 & 22.51 & 25.01 \\
\hline & 8 & 9.25 & 9.76 & 10.91 & 15.20 & 17.12 & 20.73 & 25.92 \\
\hline SEM & & 0.152 & 0.203 & 0.384 & 0.270 & 0.411 & 0.493 & 0.290 \\
\hline \multicolumn{9}{|c|}{ Main effects } \\
\hline LT & & NS & NS & NS & $*$ & NS & NS & NS \\
\hline WS & & 9.38 & 9.99 & 10.86 & $14.21^{\mathrm{b}}$ & 18.58 & 23.63 & 26.21 \\
\hline $\mathrm{HH}$ & & 9.40 & 10.18 & 11.92 & $17.07^{\mathrm{a}}$ & 20.54 & 23.50 & 25.55 \\
\hline MIX & & 9.30 & 9.83 & 11.55 & $16.53^{\mathrm{ab}}$ & 19.07 & 21.62 & 25.46 \\
\hline $\mathrm{T}$ & & NS & NS & NS & NS & NS & NS & NS \\
\hline $4 \mathrm{~cm}$ & & 9.47 & 9.91 & 11.72 & 16.33 & 20.73 & 23.84 & 25.93 \\
\hline $8 \mathrm{~cm}$ & & 9.24 & 10.01 & 11.17 & 15.54 & 18.06 & 21.99 & 25.54 \\
\hline $\mathrm{L} \times \mathrm{T}$ & & NS & NS & NS & NS & NS & NS & NS \\
\hline
\end{tabular}

LT: Litter type, WS: Wood shaving (WS), HH: Hazelnut husk (HH), T: Thickness (cm), ${ }^{\text {a, }}$ : Means within same rows different superscripts are significantly different $(\mathrm{P}<0.05)$, *: $\mathrm{P}<0.05$; NS: $\mathrm{P}>0.05$.

Table 5. Effect of litter type and thickness on foot pad dermatitis levels

\begin{tabular}{|c|c|c|c|}
\hline & $\mathrm{X} \pm \mathrm{S}_{\mathrm{x}}$ & Median & Minimum-Maximum \\
\hline \multicolumn{4}{|c|}{ Litter type } \\
\hline Wood shaving (WS) & $1.67 \pm 0.19^{\mathrm{b}}$ & 2 & $0-3$ \\
\hline Hazelnut husk (HH) & $2.33 \pm 0.21^{\mathrm{a}}$ & 3 & $0-4$ \\
\hline MIX & $2.03 \pm 0.31^{\mathrm{a}}$ & 3 & $0-4$ \\
\hline \multicolumn{4}{|c|}{ Litter thickness $(\mathrm{cm})$} \\
\hline 4 & $2.14 \pm 0.17^{\mathrm{a}}$ & 3 & $0-4$ \\
\hline 8 & $1.83 \pm 0.13^{\mathrm{b}}$ & 3 & $0-4$ \\
\hline
\end{tabular}

${ }_{\mathrm{a}, \mathrm{b}}$ : Means within same rows different superscripts are significantly different $(\mathrm{P}<0.05)$.

\section{Discussion}

Studies are continuing on alternative litter materials, mostly of vegetable origin, due to the problems in unavailability and cost of WS (Toledo et al., 2019). The use of $\mathrm{HH}$ which has been proven to be used in broiler chickens as an alternative litter material (Sarica and Cam, 2000), and the possibilities of using $\mathrm{HH}$ as litter material by mixing with WS and in different thicknesses were investigated in this study.
The effects of litter types on performance traits may vary according to the growth rate and age of chickens, litter moisture and particle size, $\mathrm{pH}$ level and climate conditions of the poultry house (Munir et al., 2019). Additionally, a small amount of litter material is consumed with the feed on the litter and this may lead to some developments in the digestive tract parts such as gizzard and intestine (Musa et al., 2012). In accordance with our results, Willis et al. 
(1997) stated that there were no differences in performance traits at slaughtering age in three litter types consisting of tree leaves, WS and $50 \%$ leaves $+50 \%$ wood shavings, and also using of tea leaves as litter does not cause significant differences in performance and litter traits (Chakma et al., 2012). Sarica and Cam (1998) emphasized that there is no difference in performance traits for the use of $\mathrm{HH}$ and various vegetative origin litter materials, however litter moisture is higher than the used for the first time. In a study using $\mathrm{HH}$ and other vegetable materials and their mixtures; $\mathrm{HH}$ was found to have higher litter moisture (Sarıca and Cam, 2000), unlike our results. However, inconsistent with our results, there are significant differences in body weight and feed conversion ratio of chickens reared on six different litter types consisting of vegetable-origin materials, newspaper pieces and their mixtures. It was determined that newspaper pieces gave positive results with vegetable origin litter mixtures (WS + newspaper and barley straw + newspaper) (El-Deek et al., 2011).,

Yamak et al. (2016) stated that the FPD scores increased due to the moisture increase of the litter. However, in our study, although there was no difference between the litter types in terms of moisture content, FPD levels differed. In our study, FPD levels differed according to the litter type and more FPD was observed in chickens reared on HH. Tercic et al. (2015) and Zikic et al. (2017) determined that the litter material of vegetable origin and different litter types affect FPD levels, in line with our findings.

The effects of standard litter thicknesses $(2-15 \mathrm{~cm})$ and low or high stocking densities (3.3-23 birds $\left./ \mathrm{m}^{2}\right)$ on performance were investigated (Toledo et al., 2019). However, in the most of studies, vegetable-origin litter materials used in different thicknesses did not cause any change in performance traits (Monira et al., 2003; Lima et al., 2018). Increase in litter thickness improves health and welfare parameters in broiler chickens (Chou-Colli et al., 2018), and a decrease in FPD development (Ektrand et al., 1997). These findings are consistent with the our results. However, doubling the litter thickness also increases the litter cost (Moesta et al., 2008). Therefore, the cost-benefit balance should be considered in determining litter thickness.

The use of the HH and MIX as a litter in broiler chickens provides the performance traits at least at the level of WS. Additionally, performance traits did not differ according to litter thickness groups. However, FPD was found higher in chickens reared on $\mathrm{HH}$, MIX and $4 \mathrm{~cm}$ litter thickness groups. It is concluded that in conditions where the material can be provided and dried sufficiently, $\mathrm{HH}$ may be successfully used in $4-8 \mathrm{~cm}$ thicknesses in the broiler production.

\section{Acknowledgments}

The data used in this study were re-evaluated by using the master's thesis (155041) named "Effects of Using Hazelnut Husks and Wood Shaving as Litter at Different Deepnesses on Performance and Litter Properties in Broiler Rearing" and some data not used in the thesis were added to this study.

\section{References}

Chakma S, Miah MY, Ara A, Kawsar MH. 2012. Feasibility of using fallen tea leaves as litter in broiler rearing. Bangladesh Journal of Animal Science, 41(1): 52-54. doi: 10.3329/bjas.v41i1.11978.

Cohuo-Colli JM, Salinaz-Ruiz J, Hernandez-Cazares AS, Hidalgo-Contreras JV, Brito-Damian VH, Velasco-Velasco J. 2018. Effect of litter density and foot health program on ammonia emissions in broiler chickens. Journal of Applied Poultry Research, 27: 198-205. doi: 10.3382/japr/pfx058.

Ekstrand C, Algers B, Svenberg J. 1997. Rearing conditions and foot-pad dermatitis in Swedish broiler chickens. Preventive Veterinary Medicine, 31: 167-174. doi: 10.1016/S01675877(96)01145-2.

El-Deek AA, Al-Harthi MA, Khalifah MM, Elbanoby MM, Alharby T. 2011. Impact of newspaper as bedding material in arid land on broiler performance. Egyptian Poultry Science, 31(4): 715-725.

Garces APJT, Afonso SMS, Chilundo A, Jairoce CTS. 2017. Evaluation of different litter materials for broiler production in a hot and humid environment: 2. Productive performance and carcass characteristics. Tropical Animal Health and Production, 49: 369-374. doi: 10.1007/s11250-016-1202-7.

Lima RC, Freitas ER, Gomes HM, Cruz CEB, Fernandes DE. 2018. Performance of broiler chickens reared at two stocking densities and coir litter with different height. Revista Ciencia Agronomica, 49(3): 1-14. doi: 10.5935/1806-6690. 20180059.

Mayne RK. 2005. A review of the aetiology and possible causative factors of foot pad dermatitis in growing turkeys and broilers. World's Poultry Science Journal, 61: 256-267. doi: 10.1079/WPS200458.

Moesta A, Knierum U, Briese A, Hartung J. 2008. The effect of litter condition and depth on suitability of wood shavings for dust bathing behavior. Applied Animal Behavior Science, 115: 160-170. doi: 10.1016/j.applanim.2008.06.005.

Monira KN, Islam MA, Alam MJ, Wahid MA. 2003. Effect of litter materials on broiler performance and evaluation of manureal value of used litter in late autumn. Asian-Australian Journal of Animal Sciences, 16: 555-557. doi: 10.5713/ajas.2003.555.

Munir MT, Belloncle C, Irle M, Federighi M. 2019. Wood based litter in poultry production: A review. World's Poultry Science Journal, 75: 1-12. doi: 10.1017 /S0043933918000909.

Musa WI, Sa'idu L, Kaltungo BY, Abubakar UB, Wakawa AM. 2012. Poultry litter selection, management and utilization in Nigeria. Asian Journal of Poultry Science, 6: 44-55. doi: 10.3923/ajpsaj.2012.44.55.

Nowaczewski S, Rosisnski A, Markiewicz M, Kontecka H. 2011. Performance foot-pad dermatitis and haemoglobin saturation in broiler chickens kept on different types of litter. Archiv fur Geflugelkunde, 75: 132-139.

Ramadan SGA, Mahboub HDH, Helal MA, Gaafar KM. 2013. Behaviour, welfare and performance of broiler chicks reared on different litter materials. Assiust Veterinary Medical Journal, 59: 9-18.

Sarica M, Cam MA. 1998. The effect of reused litter materials on broiler performances and litter properties. Turkish Journal of Veterinary and Animal Science, 22: 213-219.

Sarica M, Cam MA. 2000. Potential of hazelnut husks as a broiler litter material. British Poultry Science, 41: 541-543. doi: 10.1080/713654977.

Sarica M, Cam MA, Karacay N. 1996. Findık zurufunun etlik piliç üretiminde altlık materyali olarak değerlendirilmesi. Fındık ve Diğer Kabuklu Meyveler Sempozyumu. Bildiriler 226-234, 10-11 Ocak, Samsun.

Sarica M, Selcuk E. 1993. Yerde yetiştirilen bıldırcınların çeşitli verim özellikleri üzerine değişik altlık materyallerinin etkileri. Turkish Veterinary and Animal Science, 17: 133-138. 
Shao D, He J, Lu J, Wang Q, Chang L, Shi SR, Bing TH. 2015. Effect of sawdust thickness on growth performance, environmental condition, and welfare quality of yellow broilers. Poultry Science, 94: 1-6. doi: 10.3382/ps/peu003.

Shepherd EM, Fairchild BD, Ritz CW. 2017. Alternative bedding materials and litter depth impact litter moisture and foot pad dermatitis. The Journal of Applied Poultry Research, 26: 518528. doi: 10.3382/japr/pfx024.

Sogunle OM, Ogunjimi BA, Fanimo AO. 2006. Effect of litter depth on performance of three strains of broiler chickens. Journal of Animal and Veterinary Advances, 5: 1155-1157. doi: 10.5958/2277-940X.2017.00102.4.

Tercic D, Zolger M, Pestotnik M. 2014. Effect of different litter materials on foot pad dermatitis, hocking born and feather coverage in broiler chickens. Acta Agriculturae Slovenice, 106(2): 97-101.
Toledo TDSD, Pich CS, Roll AAP, Dai Pra MA, Leivas Leite F, Gonçalves Xavier E, Roll VFB. 2019. The effect of litter materials on broiler performance: A systematic review and meta-analysis. British Poultry Science, 60(6): 605-616. doi: 10.1080/00071668.2019.1639143.

Willis WL, Murray C, Talbott C. 1997. Evaluation of leaves as a litter material. Poultry Science, 76: 1138-1140. doi: 10.1093/ps/76.8.1138.

Yamak US, Sarica M, Boz MA, Ucar A. 2016. Effect of reusing litter on broiler performance, foot-pad dermatitis and litter quality in chickens with different growth rates. Kafkas Üniversitesi Veteriner Fakültesi Dergisi, 22(1): 85-91. doi: 10.9775/kvfd.2015.13957.

Zikic D, Djukic-Stojcic M, Bjedov S, Peric L, Stojanovic S, Uscebrka G. 2017. Effect of litter development and severity of foot-pad dermatitis and behaviour of broiler chickens. Brazilian Journal of Poultry Science, 19(2): 247-254. doi: 10.1590/1806-9061-2016-0396. 